\title{
To the Problem of Forming Creative Competence of Future Teachers
}

\author{
Sakipzhamal Uzakbaeva ${ }^{1}$, Bagdat Baimukhanbetov ${ }^{2}$, Kamalbek Berkimbaev ${ }^{3}$, \\ Bakhitzhan Mukhamedzhanov ${ }^{3}$, Rabiga Pralieva ${ }^{3}$ \\ ${ }^{1}$ Ablai Khan Kazakh University of International Relations and World Languages, Almaty, Kazakhstan \\ ${ }^{2}$ Abai Kazakh National Pedagogical University, Almaty, Kazakhstan \\ ${ }^{3}$ A. Yasawi International Kazakh-Turkish University, Turkistan, Kazakhstan \\ Email: bagdat_83-83@mail.ru, kamalbek.berkimbaev@yandex.kz, bahit-61@mail.ru
}

Received December $8^{\text {th }}, 2012$; revised January $10^{\text {th }}, 2013$; accepted January $26^{\text {th }}, 2013$

\begin{abstract}
Working out of the new pedagogical bases of formation of the modern teacher both as professional, and as the creative person possessing professionally creative competence becomes one of key problems in educational system of the Republic of Kazakhstan. Search of reserves of improvement of professional training of the teacher is displaced in a plane of formation and development of creative competence. There is a necessity of transformation of educational system of the higher school for the unique creatively developing educational system promoting formation and development of creative competence of students as the factor of successful self-realization in the profession and the preconditions of competent support of creative development of students.
\end{abstract}

Keywords: Creativity; Competence; Creative Education; Creative Competence

\section{Actuality of the Research}

Research urgency. Basic changes in high school development become a strategic problem of the modern stage of social development. The Kazakhstan educational system is intensively enriched with the European experience, to which the domestic scientific and pedagogical community refers ambiguously, and forthcoming reforms in connection with the accession of the Republic of Kazakhstan to Bologna process (In March, 2010 Kazakhstan became 46 country-participant, entered into Bologna process) put before high schools a lot of problems in addition.

Participation of Kazakhstan in Bologna process has opened for the country road to the European educational system, giving the chance to improve the quality of training, mobility of students and teachers, receiving diplomas in any point of the European area and as freely to get a job to graduates of any country of the world.

The system of mutual influence of higher education in the European educational system is a priority direction of reforming of the sphere of education in our country. The government program of a development of education of Republic of Kazakhstan for 2011-2020, confirmed by the decree of the President, shows concrete directions of development in this sphere (Governmental Program, 2010).

Important steps are made in an education system and sciences. Unification of process of science and education has given new rate to occurrence of Kazakhstan in scientific-educational world according to the principles of Bologna process. The share of the higher educational institutions which have passed independent national institutional and specialized accreditation according to the international standards has risen. It, in its turn, makes special influence on the content educational process at the higher school.
The modern vocabulary included new concept - "the academic mobility" which opens possibility to get education abroad.

First, students can go abroad to study both for limited time, and for long term; secondly, there they learn not only language, but they study also a full one term or a year course of the curriculum.

Joining of Kazakhstan to the Bologna process along with granting of two-degree diploma education, opens a way for achievement of following purposes: gives the chance to generate all basic preliminary conditions, among which curricula, teaching methods and evaluation criteria, awareness of a teaching compound; partners-participants of Bologna process give a safeguard to advantageous elements of teaching process, recognizing results and results of training of all universities; the joint program of the general controls will be created; the joint diploma of the European sample will stand out.

Working out of theoretical-methodological and technological problems of formation of creative abilities of the future teacher in the conditions of integration into world general educational system becomes one of the actual activities for high schools. Considering a wide experience of higher education and modern lines in preparation of teachers in a context of Bologna process, the pedagogical science gives great attention to working out of the basic subsystems of creative development of the future expert: theoretical-methodological, pedagogical, organizational, technological.

The analysis of philosophical-pedagogical views of scientists of the past (Aristotel, 1976; Komenskiy, 1939; Venttsel, 1911; Kapterev, 1905) has shown some problems of creative selfdevelopment of the person, and also some professional-creative components of work of the person of a pedagogical trade have been designated.

The problem of trainigof the future specialists to professional 
activity was a subject of research of such outstanding pedagogies of the past, as (Komenskiy, 1939; Disterberg, 1956; Ushinskiy, 1974; Lesgaft, 1988, etc.).

Laws and factors of formation of the creative personality of the teacher were proved in creative psychology and acmeology (Raven, 2002; Aminov, 1988; Bogoyavlenskaya, 2002; Zimnyaya, 2004; Kuzmina \& Golovko-Garshina, 2001; Kukharev, 1990; Markova, 1990; Mitina, 1998; Khutorskoy, 2002 etc.). The higher school pedagogics (Bondarevskaya, 2000; Senko, 2003; Fridman, 1988; Yakimanskaya, 2002) has closely approached. To search of ways of vocational training taking into account these laws. Some aspects of a problem are investigated in the theory and a pedagogical education technique (Kan-Kalik, 1990; Nikandrov, 1998; Slastenin \& Kashirin, 2004; Sokolnikov, 1989 etc.).

The researchers note that the found out facts are explained by the costs of the traditional paradigm of educational system, in the framework of which pedagogical activity was studied, focusing on the rate as the average of the sample. The traditional pedagogical activity directed on formation of the system of knowledge, abilities and skills of students, comes to the contradiction with modern requirements to professional activity of the teacher, focusing on transfer from teaching function on inducing to creative self-development.

From the positions of the humanistic paradigm one of the main value of education recognizes the ability of the subject to self-realization in professional activities in support of the creative potential of personality. The basis for efficient future teacher's professional development and its successful selfrealization in the pedagogical work is expressed in the structure of professional competence.

From positions of a humanistic paradigm as one of the main value of education is admitted the ability of the subject to self-realization in professional activity in a support on creative potential of the personality. The basis of effective professional development of the future teacher and its successful self-realization in pedagogical work is expressed in structure of the professional competence the establishment of which is intended to contribute to the continuous pedagogical education.

The result of professional education is acquired by the individual in the course of education the ability to perform functional duties; skill level and skill in a certain professional activity, the level of complexity of the performed tasks, i.e. professionalism. Stages of man's promotion "y stairs" of professionalism were researched by (Gershunskiy, 2003; Markova, 1996; Povarenkov, 2002; Shadrikov, 1982) and others.

An important tendency in the development of the modern higher school is the transfer of qualification approach in professional education to competence-based approach. This tendency is reflected in the fact that the strengthening of cognitive and information beginnings in the modern workplace is not "covered" by the traditional concept of professional qualifications.

During the research it was found out that in pedagogical works the issues of professionalism and competence of the teachers are raised more often than in any context and which is the subject of the study: readiness, pedagogical skills and creativity, innovative pedagogical activity, creative pedagogical thinking and creativity of the teacher (Zagviazinskiy, 2010; Kazimirskaya, 2007; Kashapov, 2006; Podymova, 2011, etc.).

Analysis of the researches devoted to the competence model of study (Kazakova, 2000; Komarovskaya, 1982; Kuzmina,
1990; Markova, 1983; Matyash, 2011; Pavlyuchenkov, 1990), shows that in concept of the terms "competence" and "competency" a key factor is the experience of individual's activity, its active position, readiness to goal setting, including acmeological component. In our research by the competence, we mean a group of interrelated and interdependent knowledge, abilities and skills, providing the fulfilment of a particular (specific) professional task, and competence is considered as the ability to access (professional) activity in the framework of the accepted competences "with the knowledge of the case," i.e., to make responsible decisions and act adequately according to the requirements of the situation.

By professional competence we understand the willingness and ability of the specialist to act appropriatly in accordance with the requirements of the situation, to solve tasks and problems methodically correct and independently as well as to evaluate the results of their activities. The competences are included in the "section" of the educational process by means of technologies, the content, the lifestyle of the educational institution, the types of interaction between teachers and students and among the students (Berkimbaev, Nyshanova, \& Kerimbaeva, 2012)

Actually the subject of the research-formation of a future teacher's professional competence, the development of teachers psychological-pedagogical competence, the formation of the individual style of activity were researched only in a few of the works of applied character (Lukyanova, 2004; Torkhova, 2006).

The content of any profession is determined primarily by the objective demands of the society, in which the given professional activity is carried out.

Formation of creative competence of the person is one of the actual problem for both the modern society as a whole and for its individual elements, in particular for the educational system.

The analysis of teachers' activity in modern secondary schools testifies to the fact that the level of practical efforts on the formation of creative competence of students in the teaching process is not high enough. Observations and interviews with teachers show that they are more interested in the degree of acquiring programme material by students, than thoroughly thought-out work on the development of students' interest in creative activity, the necessity in it, which predetermines the development of creative abilities. In the system of getting knowledge, abilities and skills the stereotypical techniques directed on algorhythmization of the students' actions are dominated (Tutolmin, 2006).

The restructuring of the educational system with the purpose of developing of student's creative abilities is impossible without changes in the content and nature of the teaching process: changes in the ratio of reproductive and creative activity of both teachers and students; the individualization of teaching process; replacement of the traditional tasks with the problematic and creative; the increase of time for independent creative and research work of students.

\section{Methods of the Research}

The basic methods of research are theoretical analysis and synthesis, comparison and concluding statistical data, modeling, research of the experience of professional activity of the future teacher of primary classes, the observation. In scientific work for the decision of tasks and verification of assumptions the 
following methods of research were mainly used: logical methods and techniques (the analysis of philosophical, anthropological, ethnographic, psychological, pedagogical, legal and other literature on the problems of professional education, synthesis, abstraction, generalization, analogy, structural-functional method and probabilistic-statistical methods); methods of theoretical knowledge (theory, formalization, deduction, the ascent from the abstract to the concrete); methods of empirical research: (observation, interviews, questionnaires, and bibliographic method; the experiment under natural conditions, comparison, description, monitoring, measurement); the system approach to the historical-pedagogical and logical analysis, generalization and analysis of pedagogical experience; modeling of pedagogical processes; pedagogical design, used for the development of regulatory and program-technological support. A methodology of experimental work was developed; indicators and criteria for evaluating the effectiveness of the identified conditions were refined; pedagogical experiment wasconducted; the educational-methodical support of educational process of professional preparation of future teachers of primary classes, aimed at formation of the creative abilities of future teachers and competences of the graduates was developed.

\section{The Results of the Research}

In the course of the research the principles of formation of creative competence of the future teachers were determined: the principle of unity of formation and development in the process of the emergence of creative competence of the future teachers; the principle of the unity of the system, competence, personal and developmental approaches in formation and development of creative competence of the future teachers; the principle of continuity and succession in the development of creative competence of the future teachers; the principle of interdependence of generalized educational trajectory and individual educational route of the future teachers; the principle of forming oriental search position of the student-teacher in relation to any aspects of the pedagogical experience.

On the basis of the analysis of theory and practice of professional training of teachers it is shown that the abovementioned principles exist the system of pedagogical education, built as a system of the organization of purposeful process of formation of creative competence of the future teachers of primary classes (Baymukhanbetov, 2011).

Organization of the pedagogical process is impossible without its science-based modeling as a system of general pedagogical training, as well as the process of formation of creative competence of the future teachers of primary classes. The modeling process consisted of the following stages: determination of the nature of the model, developing a scheme, receive the characteristics of each element of the scheme. Simulation of the process of development of creative competence in the conditions of pedagogical education by means of constructing optimal functioning of the system of pedagogical professionalism, consisting of control components and stages of professionalization; the three unity of theoretical, practical and creative components of the emerging competence; component methodological support, as well as a complex of organizationalpedagogical conditions of the development effectiveness of creative competence of the future teachers.

The data of experimental verification of the effectiveness of the methodology for formation of creative competence of the future teachers, coinside the level of higher education.

Experimental work was carried out in form of the lecture and practical lessons, pedagogical practice of students in the process of student-teacher and researcher cooperation at performing of course and diploma papers. In the context of the competence-based approach the assessment and self-assessment of the development of the students' creative erudition, creative and skillfulness of being ready to creative pedagogical activity was developed and implemented.

The author's methodology of the development of creative competence of the future teachers were consisted of: the method of compiling the individual student's glossaries, method of individual interpretation of the support schemes for studies in psychology, pedagogics; the method of information methodical maintenance of independent research activity of students, students independent work with the materials of the work-book on the printed basis, the method of the "oral magazines" (preparation and conduct of the student's pedagogical competitions, competitions of pedagogical skill), the method of creative drama (acting outs of theatrical pedagogical situations).

"Professionally-creative competence of the teacher of primary education" was implemented by: 1) lectures on creative pedagogy and psychology, stimulating creative self-development of the students; 2) practical work on the development of creative readiness for pedagogical activity; 3) training for the development and enrichment of the professional-creative skills and abilities; 4) teaching process, simulaton of problem-conflict situations, the method of case studies from the school practice; 5) task technology, the case-study method, technology of designing and design reception of the presentation.

The integrity of the methodology was ensured by a systemforming component - orientation to the formation of the students readiness to creativity in teaching activities, readiness to the competent support of the creative development of students. Analysis of the results of experimental work on using the system of non-rigid algorithms of innovative training of the future teachers allowed to reveal positive dynamics in the development of their creative competence (Berkimbaev \& Kerimbaeva, 2012).

In the course of the research we have shown that the effectiveness of the implementation of the proposed methods depends on the implementation of a complex of organizationalpedagogical conditions. Under the terms of development of professional-creative competence we understand the totality of the necessary and sufficient measures, the circumstances of time and place, to ensure the achievement of a student of a higher level of development of the creative erudition, creative abilities and skills, readiness to creative pedagogical activity, communication, and personal self-realization in their organic relationship and unity. Organizational-pedagogical conditions represent a specially simulated situation of inclusion of students to creatively developing teaching process (Kertayeva \& Bolatova, 2008).

In general scientific approach to the research of problems in the field of professional education, we have identified a set of conditions, which form a certain system.

The most common organizational-pedagogical conditions of forming the competence of the future teachers of primary education are: science-based organization, management and leadership of the process of pedagogical professionalism in the process of continuous pedagogical education; the creation of a 
single creatively developing educational system at all stages of continuous pedagogical education, development of creative atmosphere at each training session, based on competence and personality-oriented approach to improving the professionalism and creative self-development of the teacher of primary education; ensuring systematic and competence approach to professional-pedagogical education of the future teachers; implementtation of principles of continuity and system integrity of the organization of pedagogical process of professionalization.

Methodical and technological conditions that affect the efficiency of development of creative competence of the future teachers of primary education are: implementation of the principles of flexibility, mobility and optimality methodological and technological support of process development of professsional-creative competence of the future teachers of primary education; subject-activity approach to professional-pedagogical and creative professionalization of the future teachers, mastering the future teacher to the culture of the educational-creative activity, innovative technologies of education, upbringing and development of pupils; involvement in the creative laboratory of teachers by means of development of the educationalcognitive and educational-research activities of students, generalization of the best and mass pedagogical, as well as experience of creative pedagogical activity; intensify-cation of scientific-research cooperation, student and teacher-scholar.

Specific, subjective-personal conditions of efficiency of development of creative competence of the future teachers of primary education are: the enrichment of pedagogical professsionalization of the students knowledge in the field of creative pedagogy and psychology: on creative pedagogical activity, substantive, methodological, communicative, creative teacher and creative self-realization of personality of a teacher; ensuring the integration of psychological and pedagogical skills of students in the educational-creative process, in the professional and creative abilities; development of the structure of the creative readiness of future teachers to pedagogical work through optimal intellectual and spiritual, social and individual, normative and creative development.

The revealed conditions can and should be implemented in the unity and a certain hierarchy. Each of the conditions of development of professional-creative competence of the future teachers is quite independently by virtue of its specificity and purpose. However, the creative developmental potential they reveal fully only in the aggregate. Thus, we can speak about the need and adequacy of the proposed system of conditions for the effective educational work on the development of the professsional-creative competence of students.

The entire course of the experimental work has shown convincingly that in the consistent implementation of the identified conditions in experimental groups positive dynamics of formation of creative competence of the future teachers of primary education was observed.

Experimental work was carried out on the basis of the Psychology and Pedagogic Faculty of Abay Kazakh National University (Almaty City) and A. Yasawi Historical-Pedagogical Faculty of the International Kazakh-Turkish University (Turkistan City). The total samples were consisted of 12 teachers, 82 students.

The diagnostic complex was used for the assessment of the level of development of creative competence of teachers, the results of the experimental study of the effectiveness of the methodology and the pedagogical conditions, as well as the analysis of the progress and results of experimental work on the development of creative competence of the future teachers of primary education.

In the course of establishing stage of experimental work the initial level of development of creative competence of students on the basis of determining the extent of the formation of its main criteria: erudition, skillfulness, readiness was identified.

Analysis of the formation of the level of creative competence of the students of the experimental and control groups allowed to allocate relatively high, average and the low levels of development of the required quality. In accordance with the criteria and indicators (creative erudition: theoretical, pedagogical, organizational, methodical, technological knowledge; creative skill: research, communication, organizational, eurological, technological skills; creative readiness: reflexivity, insight, creativity, communication, focus on creativity, improvisation) provides a description of each of the three levels of formation of professional-creative competence of the student. One or another indicator of the formation of the professional-creative competence, in turn, was represented by five indicators, each of which is assessed according to a five-point scale. For the objectivity of the statistical measurement of the level of development of professional-creative competence group assessment of the severity of the qualities and formation of knowledge and skills were used. The group of experts was consisted of 4 teachers, 6 students, 4 researchers.

The relatively high level of development of creative competence indicates the growth of professional psychological and pedagogical knowledge due to enrich their knowledge of creative pedagogy and psychology. This level is characterized by the skills to understand and solve pedagogical situations and problems independently and originally, to find and use the original methods of training and teaching, focus on the development of students. Motivational and emotional-volitional sphere of personality focused on the creative readiness for pedagogical work, pedagogical insight, and the stability of the personal situational activity, directness to creativity, high communicative skills, improvisational style of pedagogical activity and the adequacy of self-esteem.

The average level of creative competence is characterized by lack of desire to knowledge of creative pedagogy and psychology of mastering creative abilities. The student shows good, smooth results in the theory and practice of the future professsion. It is characterized by a focus on traditional professional of training in pedagogical work. The structure of the creative readiness of the future teachers' personality is differentiated by insufficient formation, inadequate self-esteem and unexpressed personal activity.

The relatively low level of competence is expressed in mastering the basics of the profession, the use of well-known in the pedagogical theory and practice means, methods and forms of training and teaching students, its unwillingness to delve into the knowledge of creative psychology and innovative pedagogy. This level is characterized by the lack of formation of structure of creative readiness for pedagogical work, the stimulus activity, low self-esteem and unexpressed motivation.

The diagnostic program study of the levels of development of professional-creative competence according to separate criteria and their indicators has allowed us to determine the initial level in the experimental and control groups. It is established, that the presence of the necessary knowledge and professional skills of pedagogical activity of students does not mean that the 
future teachers has them. Much depends on the formation of their personal qualities, exactly-creative readiness.

Diagnostic data were taken into account at the stage of forming experiment, which included the realization of the experimental methods of development of creative competence of students; study and the fixation of the degree of implementation of the methodological recommendations; study of the level of development of professional-creative competence of the students of the experimental group on the basis of the use of identified criteria and indicators by us, as well as the analysis of practical results of creative educational activity of students; the comparison of the degree of implementation of the recommenddations in each experimental group; the final analysis and generalization of the results of experimental work in all experimental groups.

The forming stage of experimental work was carried out in the natural conditions of professional training of teachers. In accordance with the aims of this stage, we organized three experimental groups and three control groups, which had the same starting positions. The experimental groups were differing from the control groups according to the pedagogical conditions, ensuring the realization of humanistic paradigm of professional training of future specialists. A statistically significant sample was consisted of 160 students (20 students in the experimental and control groups-samples at each step of the pedagogical education).

In the experimental group, where the effectiveness of the use of the system of pedagogical conditions and the transition to the systematic training of the scientific training course was tested, the highest results were obtained, the maximum level of the professional-creative competence (professional-creative erudition + ability and skill to carry out creative teaching activities + creative readiness for pedagogical work) were achieved, mostly in the experimental group. For three years in the experimental groups the number of students, the level of development of professional-creative competence is characterized as high, increased by $26 \%$, reaching $35 \%$. In the control groups, where the model of the professional-creative training was not implemented, the results of the quality of professional training was only 8\% (Avanesov, 1982; Gronlund, 1982).

Analysis of the results of the development of creative competence in experimental student groups and their comparison with the level of development of competence in control groups allows to establish, that the use of the experimental method with the observance of the organizational-pedagogical conditions, ensuring the positive dynamics of development of professional-creative competence, had a positive influence on the increase of the level of development of professional training of the future specialists in general.

Monitoring of the dynamics of development of professsional-creative competence of the future teachers of primary education was carried out in the framework of a teaching course (pedagogy, psychology, private methods), from course to course, with the consideration of the effectiveness of the innovative educational technologies and the pedagogical conditions. Evaluation increment was in cognitive (CL-creative erudition), activity-practical (CS-creative skill), motivational-requires (CR - creative readiness) components of the development of the professional-creative competence (PCC) on a hundred point scale.

Procedure of location of the indexes of development of the components and the total indicator of development of profes- sional-creative competence was in sequential computation of the values of generalized development of the components of the desired quality in each subject, a group of subjects in each step of continuous pedagogical education, the sample as a whole.

Analysis of the results of control tests to determine the dynamics of development of professional-creative competence of the examined students according to the basic criteria showed the following:

- the level of development of creative erudition- $76.4 \%$;

- the level of creative skills - of $74.8 \%$;

- the level of development of creative readiness-73.1\%.

The total cumulative index of development of professionalcreative competence at the level of higher education is $74.8 \%$.

A comparative analysis of the generalized mean scores of development of professional-creative competence at the final stage of development of professional-creative competence of the future teachers of primary education in relation to the previous stages showed a significant increment:

- $14.6 \%$ in relation to the regular stage of development of professional-creative competence;

- of $54.4 \%$ in relation to the initial stage.

Thus, we can conclude that the use of innovative educational technologies and, in general, the program of pedagogical professionalism, had a decisive influence on an intensive growth and development of the professional-creative competence of the future teachers of primary education. The received data of statistical analysis indicate that the experimental technique positively affected the dynamics of students' readiness to creative educational activity on the basis of development of professional-creative competence, contributed to the translation of the last to higher levels.

Distribution by level of experimental work is presented in Table 1 and histogram (Figure 1).

Upon completion of the formative experiment to control the effectiveness of a research program control tests were conducted, the aim of which was to determine the levels of the formation of the professional-creative competence of future teachers of primary classes (Figure 2). The result of the experiment was a certain increase in the level of the formation of the professional-creative competence of future teachers of primary classes (Table 2).

Presented visualization of development of creative competence of the controlled students at all stages of experimental work allow us to state that, in accordance with the hypothesis of the experiment, with the use of innovative educational technologies and the pedagogical conditions, from stage to stage positive dynamics of development of the required quality in the conditions of creatively developing the teaching process of continuous pedagogical educational system was observed.

We state out the fact that the analysis of experimental work

\section{Table 1.}

The dynamics of development of creative competence of the future teachers on the different stages of professionalization in the experimental groups.

\begin{tabular}{ccccc}
\hline \multirow{2}{*}{$\begin{array}{c}\text { The dynamics of development } \\
\text { of quality at the stages of } \\
\text { professionalization }\end{array}$} & \multicolumn{4}{c}{ Significance } \\
\cline { 2 - 5 } & $\mathrm{CL}$ & $\mathrm{CS}$ & $\mathrm{CR}$ & $\mathrm{PCC}$ \\
\hline $\begin{array}{c}\text { The initial state } \\
\text { Study }\end{array}$ & 24.8 & 20.6 & 15.6 & 20.4 \\
\hline
\end{tabular}




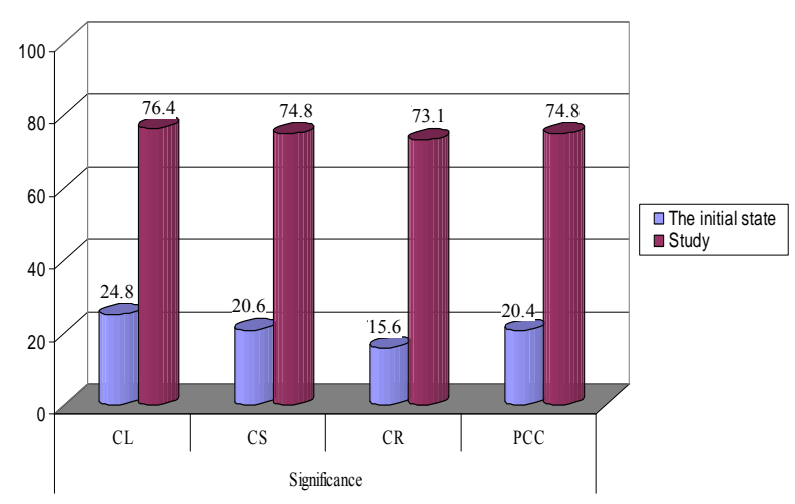

Figure 1.

The levels of development of creative competence of the future teachers.

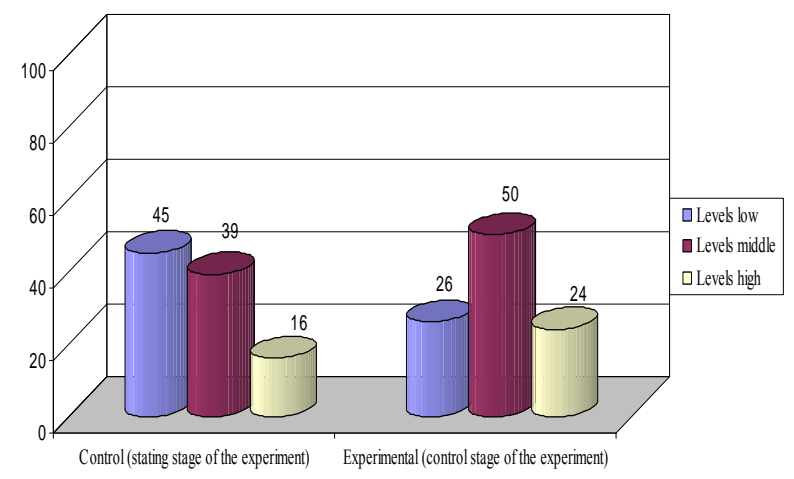

Figure 2.

Levels of the formation of the professional-creative competence of future teachers of primary classes.

Table 2.

Levels of the formation of the professional-creative competence of future teachers of primary classes.

\begin{tabular}{ccccc}
\hline \multirow{2}{*}{ Group } & \multicolumn{3}{c}{ Levels } \\
\cline { 2 - 4 } & Low & Middle & High \\
\hline $\begin{array}{c}\text { Control (stating stage of } \\
\text { the experiment) }\end{array}$ & 45 & 39 & 16 \\
$\begin{array}{c}\text { Experimental (control stage of the } \\
\text { experiment) }\end{array}$ & 26 & 50 & 24 \\
\hline
\end{tabular}

shows that the use of innovative technologies in the process of professional training is of great importance and contributes to the formation of creative competence of future teachers of primary classes. Scientific and practical research will be continued by us, and at this stage of our work we make a conclusion about the importance and relevance of the issues of using innovative technologies in the formation of creative competence of future teachers of primary classes, the modernization of the educational process, the updates of the content of the training process, which accordingly affects the change in the professional preparation of future teachers.

\section{REFERENCES}

Aminov, N. A. (1988). The physiological and psychological precondi- tions of pedagogical abilities (5 ed., pp. 71-77). Voprosy Phsyhologiy.

Aristotle (1976). Essays (p. 550). Moskow: Izdatelstvo Mysl.

Avanesov, V. S. (1982). Scientific tests in the sociological research (p. 199). Moskow: Science.

Baymukhanbetov, B. M. (2011). The role of games in the development of future elementary school teachers' creative skills. 7th International Scientific-Practical Conference "Future Issues of World of Science" (Vol. 18), Sofia: "ByalGRAD-BG" OOD.

Berkimbaev, K. M., \& Kerimbaeva, B. T. (2012). Communicative competence of future specialist. European Science and Technology Materials of the 2th International Research and Practice Conference, (Vol. 3), 9-10 May, Wiesbaden.

Berkimbaev, K. M, Nyshanova, S. T., \& Kerimbaeva, B. T. (2012). To the problem of forming information communicative competence of future specialists. International Scientific Journal Actual Problems of Modern Life. Moskow: Serie Education.

Bogoyavlenskaya, D. B. (2002). The psychology of creativity: Ucheb. Posobie dlya stud. higher educational institutions (p. 320). Moskow: Publishing Centre "Academy".

Bondarevskaya, E. V. (2000). Theory and practice of personality-oriented education (p. 352). Rostov: Publishing House of Rostov State Pedagogical University.

Disterveg, A. (1956). Selected works in pedagogy (p. 320). Moskow: Prosveschenie.

Fridman, L. M. (1988). Studies of the personality of pupils and students (p. 112). Moskow: Flint; Science.

Gershunskim, B. S. (2003). Educational-Pedagogical prognostics. In Theory, Methodology, Practice. Moskow: Flint; Science.

Governmental Program (2010). Development of education in the Re-public of Kazakhstan for 2011-2020. http://www.edu.gov.kz

Gronlund, N. (1982). Tests achievements in constructions (p. 45). London: Prentice-Hall.

Kan-Kalik, V. A. (1990). Pedagogical creativity. Moskow: Pedagogy.

Kapterev, P. F. (1905). The teaching process (p.135). Moskow: SPb.: Type-Li-Tografiya B.

Kashapov, M. M. (2006). Psychology of the creative thinking of the professional press (p. 687). Moskow: Izdatelstvo Per Se.

Kazakova, A. G. (2000). Bases of pedagogics of higher school textbook for university teachers and students of institutes of improvement of professional skill (p. 124). Moskow: IPO Profizdat.

Kazimirskaya, I. I. (2007). Organization and stimulation of the educational-cognitive activity of students of senior classes: Ucheb metod manual for the director and teachers education. Mozhar; Mozhar; Republican Institute of high education (p.165). Minsk: RIVSh. 191. Table-REFs.

Kertayeva, G. M., \& Bolatova, O. B. (2008). Organization of psychological-pedagogical research. Educational posobiye (p. 387). Pavlodar: NPF LLP ECO.

Khutorskoi, A. V. (2002). Key competencies and educational standards: Report on the department of education philosophy and theory of pedagogy. URL (last checked 23 April 2002). http://www/eidos.ru/news/compet/htm

Komarovskaya, L. V. (1982). Psychological and pedagogical issues of organization of the educational process (p.126). Izdatelstvo: Tomsk State University.

Komenskiy Yu, A. (1939). Great didactics (p. 318). Izdatelstvo: Gosudarstennoe Uchebno-Pedagogicheskoe Izdatelstvo Narlomprossa.

Kukharev, N. V. (1990). On the way to professional skills. Moskow: Education.

Kuzmina N. V. (1990). Professionalism of the personality of the teacher and the master of industrial training. Pedagogy, Moskow.

Kuzmina, N. V., \& Golovko-Garshina (2001). Acmeological theory of improvement of quality of preparation of specialists of education. Moskow.

Lesgaft, P. F. (1988). Selected works in pedagogy (p. 399). Moskow: Pedagogy.

Lukianova, M. I. (2004). Psychological-Pedagogical competence of teachers: Diagnostics and the development of the tool (p. 144). Moskow: The Scope.

Markova, A. K. (1983). Formation of motivation of teaching in 


\section{S. UZAKBAEVA ET AL.}

school-age children: A handbook for teacher (p. 96). Moskow: Education.

Markova, A. K. (1990). Psychological analysis of teacher's professsional competence. Moskow: Soviet Pedagogy.

Markova, A. K. (1996). The psychology of professionalism. Monograph, Moskow: Mezhdunarodniy Gumanitarnyi Fond "Znanie".

Matyash, N. V. (2011). Innovative pedagogical technologies: Design training (p.144). Moskow: Academy.

Mitina, L. M. (1998). Psychology of professional development. Moskow: NPO "MODEK".

Nikandrov, N. A. (1998). Values as the basis of the aims of education (pp. 3-10). Moskow: Pedagogy.

Pavlyuchenkov, E. M. (1990). The office of professional orientation in a secondary school (p. 171).Vladivostok: Dalnevost State University.

Podymova, H. P. (2011). Interactive methods in teaching and upbringing of school children. Moskow: Perspektiva.

Povarenkov, K. P. (2002). The psychological content of professional formation of a human (p.160). Moskow: Izd-Vo: YPAO.

Raven, J. (2002). Competence in modern society: The identification, development and implementation of the publishing house: Cogitocenter (p. 400). Izdatelstvo: Kogito Tsentr.

Senko Y. V. (2003). The basic competences of pedagogical activity. In Pedagogics of Development: Key competences and their development (pp. 90-97). Krasnoyarsk: Krasnoyar State University.

Shadrikov, B. D. (1982). The problem of systematization of professsional activity. Moskow: Nauka.

Slastenin, V. A. \& Kashirin, V. P. (2004). Psychology and pedagogy: A
Training manual (p. 477). Moskow: Academy.

Sokolnikov, Y. P. (1989). The experience of research of problems of education of socially active personality with the system approach. In The Problems of a systemic approach to the education of socially active individual in the Junior school age (p.158). Moskow: Prometheus.

Torkhova, A. V. (2006). Variative plurality as the basis of the vocational teacher training (pp. 57-59). Moskow: High Education Today.

Tutolmin, A. V. (2006). Formation of professional and creative competence of the future teacher of primary education: Methodology and analysis of experiment (p. 250). Glazov: Glazov State of Pedagogical Institute.

Ushinskiy, K. D. (1974). Collection of works. Moskow: Akademya Pedagogicheskikh Nauk RSFSR.

Venttsel, K. N. (1911). Ethics and education of a creative personality: (The problem of morality and upbringing in the light of the theory of the free harmonic development of life and consciousness) (p. 388). Moskow: Knizhnoe izdatelstvo Tikhomirova.

Yakimanskaya, I. S. (2002). Personally-Oriented education in modern school (p. 96). Moskow.

Zagvyazinskiy, V. I. (2010). Research activities of the teacher (3rd ed.). Moskow: Academy.

Zimnyaya, I. A. (2004). Key competence of how to effectively target the basis of competence approach in education. Moskow: Issledovatelskiy Tsentr Problem Kachestva Podgotovki Spetsialistov. 